\title{
SOUND POETICS IN CLAUDE DEBUSSY'S ART OF PLAYING THE PIANO
}

\section{Natalia Riabukha}

\section{INTRODUCTION}

On the boundary between the $\mathrm{XIX}^{\text {th }}$ and $\mathrm{XX}^{\text {th }}$ centuries, the creative personality of Claude Debussy is associated with reforms in the sphere of music language, the destruction of artistic - aesthetical norms of classic romantic art and thinking methods. Ontological nature of C. Debussy's sound sensation of reality resulted in a rejection of the anthropocentric world picture, where the image of the lyrical hero, his mental passions and feelings hustle out "off-screen", due to which the symbolic significance of music strengthens. Such intellectual sound sensation of the objective world, as well as the way of its modelling, is brand new for the $\mathrm{XX}^{\text {th }}$ century music. Therefore, in the world culture, C. Debussy is considered to be a creator of the new concept of the sound image of the world, which caused an iconic turn in the artistic consciousness of the artist of the next generations.

A pivot to the phonic level of the musical form organization, to timbresonorous peculiarities of sound, is an innovative feature of the C. Debussy's artistic method, which becomes a key one in the Contemporary times' music (in particular, in the works of Luigi Nono, György Ligeti, Giya Kancheli, Edison Denisov etc.) A new level of sound-musical self-consciousness, the innovative changes in the structure of music being and reinterpretation of the traditions of romantic pianistic culture, have certainly affected the concept of the piano sound image, have an impact on broadening its artistic-acoustic potential, multicoloured treatment of its sound palette. Thus let us reveal the specificity of sound-image thinking of the composer, which caused treating the piano sound and image and mirrored the ontological concept of the sound image of the world - an intonation - contonnational sound sensation of the $\mathrm{XX}^{\text {th }}$ century being.

Contemplation of reality was the main method of C. Debussy as an impressionist composer. His attention was fixed not on the external "photographic" image transmission accuracy, but the internal vision, conception, and perception of an object "from inside". That is why the artist is interested not in the historic reality and changes in society. The composer is driven by a desire to reproduce the sound sensation of a moment, the uniqueness and transience of time in the sound space of the environment. Contemplation of the play of light, shadow, and water, images of flowing 
clouds in the sky, which in and of themselves are live music of the world, arouses the desire to fill own music images with audiovisual visibility, spatiality and the internal psychologism.

Consequently, the novelty of C. Debussy's music consists in a new sound poetics, which is based on visible feeling of limitlessness and multidimensionality of sound space, where sonorous qualities of sound strengthen - sound-timbre colouristic (overtone colouring of sound), which is "intensified" by polymodality, tonality and melodiousness - preponderance of poly-melodious, polytonal relations over modal function. The sound structure as a unit of meaning reduces to the timbre-tone, harmony-timbre, themetimbre and texture-relief scales. The composer had the feeling of the sonorous concept of music, drawing attention to the phonological level of music whole organization.

\section{The peculiarities of sound image thinking of C. Debussy}

Not withdrawing from the romantic idea of programmability, C. Debussy takes the holistic image of the lyrical hero "off-screen" researcher connects the sound image system of C. Debussy's music language and speech organization with motives of symbolist poems, translated, for instance, into opera genre. In Pelléas et Mélisande (opera), C. Debussy embodied in sounds "the symbolist concept of Maeterlinck's theatre", in other words, the composer found "the music equivalent" to poetic symbols, based on the method of sound symbolism". 2 Modern musicologists, like L. Kokorieva, N. Klymova ${ }^{3}$, S. Yarotsinsky ${ }^{4}$ analyze the logic of C. Debussy's music language organization based on phonetic, intonation and semantic relation of the poetic text and the sound-music conscious of the artist. The researchers uncover the symbolism of C. Debussy's sound image thinking on the level of image-state drama, which gradually develops in the time and space of music drama.

The influence of poetic symbolism on sound image thinking of C. Debussy is obvious. On several occasions, the composer expressed the following opinion: "Beauty must appeal to the senses, must provide us with immediate enjoyment, must impress us or insinuate itself into us without any effort on our part!" 5 . This is the main motto of the composer, his sound ideal to praise the beauty of the world in the entirety of symbolic expression.

${ }^{1}$ Kokoreva, L. (2010). Claude Debussy: the study. Moscow: Music. P. 12.

${ }^{2}$ Kokoreva, L. (2010). Claude Debussy: the study. Moscow: Music. P. 33.

${ }^{3}$ Klimova, N. (2011). "Pelléas et Mélisande" C. Debussy To the question of the essence of French musical symbolism. Kyiv Musicology. Kyiv. P. 98.

${ }^{4}$ Yarotsinsky, S. (1978). Debussy, Impressionism and Symbolism. Moscow: Music. 232 p.

${ }^{5}$ Debussy, C. (1964). Articles, reviews, discussions. Moscow: Music. P. 169. 
However, in the instrumental music the nonverbal being of sound symbolics "the words that sound" puts the traditional allegorical sense on the back burner.

The composer gravitated towards exclusively musical, nonverbal symbolism, which predetermines the internal and external conceptual vectors. On the one hand, the musical cryptography of C. Debussy created various sound structures - motives-symbols (melodic-intonational and rhythm-texture complexes), which characterize imaginative symbolics of the programming content and sound-symbols (tones, fixed intervals, consonance) that uncover the hidden meaning of "tonal symbolics" (expression by L. Kokorieva ${ }^{6}$ ) in the composer's text.

On the other hand, these sound structures, acquiring the corresponding instrumental embodiment, personify through timbre-acoustic characteristics of the musical instrument. Phonic properties of the sound-tone (timbre, dynamics, pitch, volume, space localization) make the "inner life" of the musical sense perceptible, where the artistic conscious is directed by imaginary sound images in their specific verbalization through the instrumental image. This is the way the semantic field of the instrumental symbolism is created.

The unity of perception of seeable (imaginative) and conceptual (symbolic) in the system of its creation - the instrumental birth of sense mirrors the nature of sound -image thinking of C. Debussy, which gravitates towards sound-symbolic perception and reproduction of reality. Such way of artistic thinking may be called eidetic, which means thinking by "clear" or absolute phenomena of musical sense - sound images. In such a way, the music of C. Debussy uncovers the specificity of sound-image thinking, which in the dynamics of formation-contemplation over the beauty of the instrumental-sound image, directs "the reflecting conscious" of a human being to the hidden fundamental nature of the musical Logos.

Postromantic "illusory-pedal pianism" of C. Debussy ${ }^{7}$ resulted in the birth of the new idea of the instrument. The interrelation between space qualities of sound and artistic-acoustic capabilities of the pianoforte is stipulated by synaesthetic paradigm of sound image thinking, which reflected in strengthening the meaning of the visual threshold in music and art in general. In this sense timbrecolouristic palette of "Estampages", "Images", prelusion of C. Debussy is close to searching for transmission of visible, hearable and perceptible in the artistic canvas of Claude Monet, Pierre-Auguste Renoir,

\footnotetext{
${ }^{6}$ Kokoreva, L. (2010). Claude Debussy: the study. Moscow: Music. P. 146.

${ }^{7}$ Gakkel, L. (1976) Piano music of the XX century: essays: Moscow-Leningrad: Sovetskij kompozitor. P. 21.
} 
symbolist poems of Stéphane Mallarmé, Charles Baudelaire, Arthur Rimbaud. The transmission of the sound sensation of nature, the metaphoricity of the sound representation of images is agreed in the music of Claude Debussy with synchroneity and symbolism of sound sensation, determined by auditory spectrum, poly harmony and spatiality. Herewith, as S. Chashchyna puts it, the role of timbre-phonic resources and articulatory performance techniques dramatically increases up to their individualization, which leads to the thematic function of sound colouring and sound extraction technique ${ }^{8}$.

Within the meaning of Claude Debussy, the pianoforte sound and space act as symbols of eternal ideas, as long as their primary properties renew metaphysical character, sound contemplation, dipping into the fundamental nature of sound, the symbolism of outlook. This to some extent coincides with religious-philosophical ideas of Ancient Eastern Civilizations regarding sound-absolute as a philosophic category, treating the laws of space and time organization, the ontological essence of the Universe.

Thus, Claude Debussy was one of the first composers for whom the sound image of the piece of music had not only aesthetical meaning but also served for the achievement of the main goal - extension of the limits of sound image conception and thinking which affords the opportunity to see and hear the words "in a new focus". The set goal was a kind of a push to the artistic discoveries of the composer.

A brand new vision and the way of modelling the sound image of the world were revealed in the multiplicity of senses and way of sound, embodied in nonverbal - sound form with the participation of musical-content and extramusical associational ideas. The sound as a physical, psychological and artistic phenomenon "is targeted" through the following spatial features, like weight, volume and density. A creative search of the composer, directed to revealing "the inner life" of musical sound, manifested itself on the phonicacoustic micro-level of the musical piece and compositional macro-level. This led to the development of the role of individual dynamic, timbre, articulatory and spatial features of the sound as "a living musical body" (L. Gakkel"), the increase of their semantic charge on the musical time unit.

The direction of the composer's attention to the sound microstructure (attack, development, retardation phases), illumination of its timbre-colouring

${ }^{8}$ Chashchina, S. (2012). Instrumental creativity of Claude Debussy: from sound-as-an-atom to sound-as-a-process. Musicological forum-2012: Proceedings of the international scientific conference 19-22.11.2012. Moscow: Russian Academy of Music named after Gnesins. P. 12. Retrieved from: http://test.gnesin-academy.ru/sites/default/files/docs/Chashchina2Mb.pdf (accessed 10 January 2020).

${ }^{9}$ Gakkel, L. (1976) Piano music of the XX century: essays: Moscow-Leningrad: Sovetskij kompozitor. 
properties by mode and harmony means, are reflected in the architectonics of the musical form, which not always coincide with classical principles. Processual nature, which becomes active in the process of listening attentively and reproducing the sound drama by the performer on various scale levels, forms an expressively-conceptual symmetry between micro- and macroprocesses of time and space model of the piece of music, as it is evidenced by the transformation of the romantic concept of the sound from the atomic (sound-atom) into postromantic - processual (sound-process) ${ }^{10}$. The sound is treated not as a material but as a model, a concept that contains many conceptual boundaries of the sound image of the world becomes not only a style-forming factor of the pianoforte music of C. Debussy but also an important dominant character in the $\mathrm{XX}^{\text {th }}$ century music.

Air atmosphere, cloudiness of sound expression and "overtone principle of writing" (L. Gakkel ${ }^{11}$ ) of C. Debussy caused the peculiarity of treating the timbre-acoustic capabilities of the pianoforte. Regardless of the composer's tendency towards "muted" sounding ${ }^{12}$, the composer advanced claims on the pianoforte, as the solo concert instrument, to which there are subordinated the most diverse inflexions of sounding with the use in equal measures both the right and the left pedals. A special impression on the audience during the performance of C. Debussy made the richness of pedal effects (long-term bass sounds, organ points, vibrating pedal ("half-pedal"), a combination of different pedals $)^{13}$.

Extension of sound and expressive capabilities of pianoforte is agreed with the internal psychological preconditions (which are based on the intersection of various modalities of perception - hearing, visual, tactile-kinesthetic), as well as with the external parameters of acoustic environment (architectural, acoustic, reverberation characteristics of the rooms).

Thus, the desire to "see and hear the world in the other light" (dictum by H. Orlov) afford the subject of creative work unlimited opportunities to express the deep-laid, voluminous and multidimensional sound image of the world, which is stipulated by the transformation of the romantic concept of the sound and the pianoforte in the postromantic model of the spatial impression of the instrumental sound.

${ }^{10}$ Chashchina, S. (2012). Instrumental creativity of Claude Debussy: from sound-as-an-atom to sound-as-a-process. Musicological forum-2012: Proceedings of the international scientific conference 19-22.11.2012. Moscow: Russian Academy of Music named after Gnesins. P. 2. Retrieved from: http://test.gnesin-academy.ru/sites/default/files/docs/Chashchina2Mb.pdf (accessed 10 January 2020).

${ }^{11}$ Gakkel, L. (1976) Piano music of the XX century: essays: Moscow-Leningrad: Sovetskij kompozitor. P. 21.

${ }^{12}$ Yarotsinsky, S. (1978). Debussy, Impressionism and Symbolism. Moscow: Music. P. 190.

${ }^{13}$ Long, M. (1985). At the piano with Debussy. Moscow: Soviet composer. P. 111. 
Onto-sonological sensation of the music was also determined by the stylistics of the impressionism. Debussy follows the researches of painters in the sphere of transmission of visible, heard and felt space not only in the momentary impressions, moments of the time but also in the canvas. "The Joyful Island" (1904) - a piece is monumental by its form and quasiorchestral writing, which oversteps the limits of the pianoforte style. The sound-image thinking of the composer is polytembral (provides thinking by orchestral timbres, which are the symbols of artistic epochs - the flute, violin, horn or ideally - the oat); polygenre (predetermined the use of dance rhythms, rhythm and intonations); polysemantic (sound play with images and their meanings). This is a kind of musical transcription to the picture The Embarkation for Cythera by Jean-Antoine Watteau ${ }^{14}$. Three themes - a joyful tone of the first theme transfers the image of "festive season in Rome" (an expression of Marguerite Long) or "foaming wave" (A. Alshwang ${ }^{15}$ ), which sounds like a calling. The dynamic tone is kept until apotheosis hearing of metal tubes with the whole-tone rising motion and dancing theme (A-major, 3/8), which are hosted in a coda.

Unleashing the inner potential of the sound or a complex of sounds (distance, chord, figuration) as a self-sufficient sonorous element with the individual timbre-registered, dynamic and articulatory characteristics, observation over his inner life on the macro-level of the musical whole gives birth to a new principle of sound organization, related to the functional logic disorder. This stimulated the composer to the resemantization of the musical language, expansion of the phonic properties of speech system in the conceptual field of the instrumental forms of expression.

C. Debussy's sound images the same as pictorial ones are born spontaneously, instantaneously, even uncontrollably, as a sketch, therefore, there might be heard the spatiality, lightness and "aquarelle" of forms in his music. A sense of colour and light in "The Sea", "Nocturnes" or "Games" by C. Debussy "almost visible" as "a free and unconstrained movement of sonic flows", "much closer to the direct feeling of the animated nature"16. It was stipulated by the well-considered and painstaking attitude of the composer to all even the smallest details.

The development of texture type thematism is carried out according to the principle of "musical montage" (E. Denysov). Motivic work of C. Debussy impresses by free quasi-improvisational variation of the intervalics based on

\footnotetext{
${ }^{14}$ Alschwang, A. (1963). The piece of K. Debussy and M. Ravel. M.: State Music Publishing House. P. 82.

${ }^{15}$ Ibid

${ }^{16}$ Denysov, E. (1986). Contemporary music and problems of the evolution of composer technique. Moscow: Soviet composer. P. 111.
} 
the modal-harmonious complex which is felt in the music of Anton Webern ("permutation of the series and its meshes", which is projected both on the horizontal and vertical of the texture). According to L. Hekkel, the C. Debussy's style is characterized by "phonic principle" of writing, "an illusion of timbres", "the polyphony harmonic layers" - "harmonic bodies".

In the pianoforte art of C. Debussy there occur the expansion of the artistic functions of the sound, timbre, harmony, mode, which is the evidence of the composer's gravitation towards sonorous logics of the pianoforte writing. It is manifested on different levels of the musical whole: phonic - the sound-tone as the "harmonic nucleus" becomes the main sense-forming element of the musical language, the source and the pivot of the composition development; texture the correlation between the sound relief and background complexes (density, weight, volume, space localization), the values of which influences on spatial volume model of the sound structures organization; tonal-compositional polymodality, which form the time aspect of the sound perspective.

The originality of sound colours, timbre coloristics of writing, phonism, spatial model of sound organization, polymodality of the composer's writing of C. Debussy emphasize the trend, which became characteristic for the whole $\mathrm{XX}^{\text {th }}$ century music - this is the intensification of the meaning of the phonic and compositional levels of the musical whole, which is evidenced by disconcentration of thematism to melodious singing warm-up, focusing on the sphere of timbre-phonic sense of rhythm, which in its turn leads to weakening of tone relations in the music development.

In the creative works of C. Debussy, there were drawn up the new ways of timbre- coloristic renewal of the pianoforte texture as the time and space model. The starting point in it was the concentration of attention on the plastic nature of the pianoforte sound which led to increasing of the role of timbre, colour, sonority, phonism as the main means of form-making. The main role in the reproduction of the pianoforte sound image play the articulatory techniques and ways of sound extraction, dynamic and registered amplitude, the nature of the interaction between texture movements and timbre complexes (intervalics of vertical complex, the nature of tones distribution, chord consonance). All the above-mentioned in combination with the performance mastery creates an inimitable sound image of the pieces of music, namely its timbre coloring.

The instrumental timbre personifies in the context of associative and imaginative characteristics of the music: the images of Pan, the sea, clouds, landscape backgrounds, which transmit the vibrating atmosphere of the air, an iridescent play of waves and clouds. There are used different techniques coloristic writing - the coloristic treatment of harmony, timbre, texture, subordination of the melodious thematism to the background one, an introduction of the variable-based development method. 
Impersonation and objectness, the feeling of the living plasticity of the sound are peculiar not only to C. Debussy but the French music in general ${ }^{17}$. The main condition for the sound-image thinking becomes the live demonstration of pictures and phenomena, reflected in the specific instrumental - acoustic images.

The poetics of C. Debussy's pianoforte is extremely diverse, is full of the composer's impressions about the environment in all its diversity, which is instantaneously caught and transmitted in the spatial sound-image imagination. The typology of sound-images in pianoforte creative works of C. Debussy is presented in the following patterns: a musical landscape, a psychological profile, genre-character episodes, ancient genres, artistic and associational programming, "clear" or absolute miniature.

The world of nature was always an unchangeable source of the composer's inspiration. Most images of the instrumental music praise the contemplative images of a human being, staying face to face with nature. Through the lens of music-like natural beauty and hedonistic concept of joyfulness in contemplation over it, the composer sprinkles the light images of calmness, melancholic sadness, going past "darkness" Verlaine's motives of the solitude, grief and skepticism, "The Flowers of Evil" by Charles Baudelaire. Metaphorical parallels between natural disasters and inner state of a person connect the poetics of symbolism with attempts of Claude Debussy as the impressionist composer to feel "the music everywhere" (as Verlaine put it). Therefore, the basis for the sound-image thinking of Debussy is the pictorial principle of "dissolution" of the image of human being against the background of the landscape, effects of light and shade and the colour. Valuable is not the similarity of appearance but the contemplation itself, not the inner condition of the one who contemplates, but the influence on the sound image of light perception by the recipient. It causes the increase of the volume of the sound space of the pieces of music, where the main constructive function performs the chord-harmonious complex with its timbre-sonorous characteristics.

An individual sound sensation of the world and the peculiarity of the artistic manner of C. Debussy consists in the unity of phonism and spatiality, which is created due to artistic and pictorial vision and for the achievement of the sound image authenticity. The phonism is felt in the multiregistered composition of the texture with high contrasts, which emphasizes sound fullness of the harmonic vertical and the wealth of timbre-sound palette of the horizontal. The associative relation with spatiality causes a polyphonic texture, which is divided into the background and basic layers. The

${ }^{17}$ Asafiev, B. (1975). French music and its modern representatives. Foreign music of the twentieth century. Moscow: Music. P. 113. 
background layer in the instrumental texture becomes the means of creation of the sound (registered) perspective, thanks to which the sound of chords, sound connections continue in space and time. In the background sound space registered height frequently coincides with the width of the location of the thematic nucleus in the filling-in parts followed by registered transference. In such a way there is created a space of tone-paining, wherefrom the very beginning of the piece of music there is established an atmosphere of diving into the internal contemplation over the world.

Love for the pianoforte is manifested in special magic sounds sensation of the instrument, which Marguerite Long characterized in the following way: "How to forget the flexibility, softness, and depth of his touches! Alongside with that he was sliding over the keyboard with such an incredible tenderness and was pressing it, achieving the sounds of unprecedented expressive strength. Here is his secret, the pianistic enigma of his music. Therein lies a special technique of C. Debussy: softness with every touch and colouring he achieved by only playing the pianoforte" $" 18$.

The pianoforte sound of Debussy is energetically saturated with "breathing" pedal. The psychological dive into the organized sounding is inherent in such sound aesthetics, where the tenderness and daintiness of harmony were emphasized. The images of sound require the use of the following epithets "transparent", "velvet", "light", "airy", "azure", "delicate", "tender", "quivering”, “weird”, “deep", "secret”, “smooth", "unlimited", "damped". Atomic strength, radiation of sound, sound euphoria and hedonism - all these surrounded Debussy. The pianist has to feel the sound with the tips of the fingers. Even the dynamics of forte is achieved with a maximum pressing the keys preserving the softness of touch. Such technique of sound extraction is stipulated by the articulation details, such as divisi, tremolo, which under no circumstances does not decrease the sound intensity. The absence of timbre-dynamic "pressing" the keys was also stipulated by the dynamics of the piano, pianissimo in combination with author's instructions "tres soutenir" (very composedly), "doux et expressif" (tenderly and expressively).

\section{Poetics of sound images in the pianoforte creative works of Claude Debussy}

The poetics of sound images in the creative works of Claude Debussyy is characterized by the following typology:

1. Sound representing sound images are based on imaginative and associative perception and the principle of sound-imitation. It embodies the

\footnotetext{
${ }^{18}$ Long, M. (1985). At the piano with Debussy. Moscow: Soviet composer. P. 36.
} 
visible, seeable and hearable real worlds of sound images, in other words, translates everything "visible through the hearable" (as V. Tsukkerman put it). To the above-mentioned refer the sound images, which are connected with any manifestations of the sound natural environment.

2. Artistic-associative sound images cause synaesthetic parallels and interspecific relations with other arts (poetry and fine art), which stimulated the composer to the creation of program pieces or cycles of pieces.

3. Symbolic sound images - reflect not only the subjectivity of sensual and emotional perception but also model the inner condition-the feeling of the image. These are the images-symbols of the "perpetual motion of nature"19, which are distant prototypes of the romantic world, ideal of the travelling artist, the images of the time (the ancient world, medieval period); folklore images, landscape images (embodiment of different emotional states, romantic sensuality, spring freshness), which transmit the theoretic contemplation of the world, aspiration for the romantic beauty and an unattainable ideal of everlasting happiness, calmness.

The above-mentioned types of sound images act in C. Debussy's creative sphere of concepts as dominant image-bearing spheres, symbolic structures, "bundles of the world view". For example, the image of water, which is often used by the composer in the program names of the pianoforte, orchestral pieces of music, performs the function of the archetypical symbol, "a marker of purification, renewal and renaissance in the Biblical discourse" (as N. Shvydka put it ${ }^{20}$. The sound image of water in the creative works of C. Debussy was given a special meaning, in other words, was symbolically reconsidered. It was primarily the image of clear water, which reflects the world in its conceptual many-sidedness, allegorical incapability to depict the reality as a fixed verity, clearing the consciousness out of everything that was in the past. The sound image of water reproduces a timeless interpretation of the everlasting source of the world reflection.

Let us enumerate the basic principles of the sound image thinking of C. Debussy, which were marked, in the interpretation of the sound image of pianoforte: sound visibility, audiovisual aids, the physical sensation of the instrumental sound; time and space sensation of the instrumental texture from separate tone to background structures; the introvert type of the soundmusical expression, absence of conflictive dramatism. These features make the spatial-contemplative type of sound image thinking of Claude Debussy.

${ }^{19}$ Kunitskaya, I. (1978). Musical landscape of Debussy. Problems of landscape in European art of the 19th century: materials of the scientific conference. M.: Soviet the artist. P. 287.

${ }^{20}$ Shvidka, N. (2015). The archetypal symbol water as a marker of purification, renewal and renewal in a biblical discourse. Theoretical and applied problems of current philology. Vol. 1. P. 160. Retrieved from: http://nbuv.gov.ua/UJRN/tppsf_2015_1_24. (accessed 10 January 2020). 
The interpretation of the sound image of the world in the creative works of Claude Debussy is related to the formation of the timbre-sonorous concept of the sound, which appeared to replace tonal-harmonic principles. The sound innovations of the French composer provided the psychological, graphicsemantic and semiotical transformation of the sound image of the world, stipulated by sonorous ("pantimbre") method of musical thinking ${ }^{21}$. Sonorous principles of interpretation of timbre abound in pianoforte preludes of Debussy: an effect of sound "spot" with pentatonic glissando, coloristic comparison of registers, triads, chords, expansion of texture.

In the pianoforte texture, there were distinguished the features of the orchestral writing of C. Debussy: three-line score, register decomposition, magadizing, chord parallelism, repetition, quasi-sonorous texture, which create the spatial effect of sounding. Pianoforte pieces of C. Debussy "sound as orchestral scores, where the voices live their independent life of solo instruments, and all the sound extraction techniques are strictly differentiated according to their colour ("timbre coloured pianoforte"!) - as Yu. Kudriashov put $\mathrm{it}^{22}$.

To the C. Debussy's favourite orchestral timbres belonged woodwind instruments and bowed instrument, as long as only due to them it was possible to achieve the most expressive and rhythmical diversity. The example of tonal personification of "clear" instrumental timbres is Sonata for Flute, Viola and Harp, where the Flute embodies the image of nature, the Viola - emotional softness, and the Harp - the transparence of the world ${ }^{23}$. Timbre semantics is related to the composer's ability to identify the colouring of the sound of this or that musical instrument with a specific image, the inner state of mind or a mood, which appears when observing the changes taking place in the world.

Debussy felt the nature of each musical instrument perfectly well, was able to find for each of them the specific musical replicas, intonation expressions, using the whole technical potential. Unforgettable for the audience remains the images of the flute sounding in "The Afternoon of a Faun", the English horn in "Clouds" from Nocturnes for the orchestra etc.

Taking into consideration the knowledge of the laws of acoustics, the knowledge of the overtone capabilities of timbre, harmony, C. Debussy considers chords as the "sound autonomous complexes", the components of the spatial sonorous field, where even human voices are treated as a colourful element. The sonoristic interpretation of the sound is based on free play and

${ }^{21}$ Kudriashov Yu. (1985). The influence of Debussy on the timbre thinking of the twentieth century. Problems of musical science: Collection of scientific works, vol. 6. Moscow: Soviet composer. P. 245.

${ }^{22}$ Ibid. P. 271.

${ }^{23}$ Ibid. P. 249. 
movement of tones, chords, harmonic complexes, which have a different structure, dynamics, register distribution. Herewith the sound complexes-spots dictate the terms of thinking by relief-phonic timbre spectrums - a colourful, phonic interpretation of the texture material, which causes new sound image presentation and associations.

The diversity of timbre colours of the pianoforte sound image is the evidence of the transmission of principles of orchestra writing and the wealth of orchestral colours to the pianoforte texture, which resemble the palette of impressionist painters. The whole attention of the composer was concentrated on the expression of the smallest details, coloristic variation of the image, enriched by the possibilities of time and space contrasts and non-conflict modulations. For C. Debussy it was important to transmit the instantaneous, momentary impressions, comprehended by "spiritual vision" of the world. Therefore, the uppermost in the C. Debussy's music is not only the dramaturgic unfolding of the image. The attention is concentrated around one moment in time - an image of impression, presented in different shades and details. On the one hand, the instantaneousness, laconism and semantics of the detail is the evidence of the gravitation towards miniaturism. On the other hand - the spatial lightness was fixed in a complex of texture-performance means ${ }^{24}$. Different coloristic effects, picturesqueness, symphonity and orchestra nature of writing inherent in many pieces of music by C. Debussy, is the evidence of the immensity, comprehensiveness of the composer's thinking.

Pictorial impressionistic aesthetics of young and mature C. Debussy to some extent is reflected in the sound image world of his late creative works. The pieces of music created within the period from 1914 to 1918 - Twelve Etudes for Pianoforte, as well as Sonata for the Cello and pianoforte, Sonata for Flute, Viola and Harp, bring "neo-classical" accent in the sound image world of C. Debussy. Appealing to stylistic stores of the past epochs, the composer suggested own interpretation of the form, harmony, mode, rhythm, motive and intonation complex and development scheme in the dramaturgy, which is the evidence of the role of the founder of new musical ontology of the $\mathrm{XX}^{\text {th }}$ century, which uncovered the innovative methods of reproduction of the sound image of the world.

During the late period, the impressionistic "colouring" of the sound thinking of C. Debussy, who was characterized by the ability to create the effects of twinkling, edge fuzziness, smoothness of mode and harmony forms, conflicted with "cleanliness of timbre" ${ }^{25}$, which reveals the aesthetics of the

\footnotetext{
${ }^{24}$ Dovzhinets, I. (2006). Plenary effects reproduction in piano music (The thesis of Candidate of Art Criticism). Odessa National Musical Academy named after. A. V. Nezhdanova. Odessa.

${ }^{25}$ Izmailova, L. (1971). Pure harmonic tones in the music of K. Debussy. Musicology: collection of books. Art. Vol. 5. P. 187.
} 
beauty of the unicolor touch (as in the divisionism - the separation of colors into individual dots or patches which interacted optically). Over the last years of the composer's life, the pianoforte music was characterized by an aspiration for tone-painting with "clear colours" as a manifestation of cleanliness and locality of mode-harmony style ${ }^{26}$. It creates a colouring of clear, refined sound vibrations, uniformity of sound forms with the focus on listening to clear timbres (consonances, natural-diatonic combinations, instantaneousness of changes of intonation and harmony contours). All the above-mentioned is indicative of the fact that the composer "saw the world, not the colours" ${ }^{27}$. Timbre functions as a colourful-phonic element and a structural factor (timbre-intonation unfolding of the sound idea, timbre differentiation of the tonalities stipulates the dramaturgical principle of contrasts -comparison of the parts of the composition).

Image-expressive characteristics of "clear timbres" uncover the fastidious world of sounds of the late Debussy: sparse flowers, illusionary timbres, twinkling of double lines, "vibrating" unisons. In combination with program conception of the pieces these sound images push the boundaries of program miniature, as long as they become an inseparable part of the sound image of the world at the beginning of the $\mathrm{XX}^{\text {th }}$ century.

During the third period of the creative works (the years 1903-1917 according to periodization of A. Alshwang) Debussy "was going to meet the trends of artistic thought, which appeared to replace the impressionism" 28 . His late pieces were characterized by polytonality, polygenre, drive to texture multilayer and in general to the extension of the sound range of expression. The sound complexes combined the multiplicity of images of the world in the contract synchronism of the polyphonic vertical, genre differentiation, which reflects the superposition of different emotional reactions.

The unfolding of the sound images takes place on the basis of the dynamics of form making pulse. The style of late pieces is characterized by "a harmony of clear sound forms",29, such as quartal superposition, sound complexes within the limits of non-harmonic scale, whole-tone scales, free interval combinations, mode-harmony joining of different texture layers, which is indicative of the presence of polyphonic pithiness.

${ }^{26}$ Ibid. P. 185.

${ }^{27}$ Ibid. P. 186.

${ }^{28}$ Kunitskaya, I. (1978). Musical landscape of Debussy. Problems of landscape in European art of the 19th century: materials of the scientific conference. M.: Soviet the artist. P. 9.

${ }^{29}$ Izmailova, L. (1971). Pure harmonic tones in the music of C. Debussy. Musicology. Vol. 5. P. 188. 
Let us appeal to analysis. The program title of the Suite for two pianofortes "in white and in black" ("En blanc et noir", 1915) is an allegorical hint, which corresponds to symbolist aesthetics - a principle of "the expression of the inexpressible". The antithesis of white and black is the symbolist projection of the perpetual theme of the human life drama: light and darkness, love and death, which run through almost all the creative works of C. Debussy (especially in Pelléas et Mélisande (opera). The images are just at the hints in the titles dedicated to prominent people, contemporaries and friends of the composer and in small poetic epigraphs.

$\mathrm{Yu}$. Kremliev points at the fact that the suite is directly related to the theme of the war (1914-1918). If the first part, as the scholar puts it, is the "tone-painting of the hustle and bustle of the war", then the second one is the "tone painting of the military landscape with the echoes of fanfares, disturbing noise, distant gun fires"30. However, the expressed sense is not in depicting the horrors of the war, sorrow over those killed in a battle but in avoiding everything negative. According to C. Debussy, "the war is the state that contradicts the thought". The contrast between the parts mirrors the collision of the hustle and bustle of Paris at war and absolute calmness, presented by nature, a possibility to create in silence, which was found (during the trip to Pourville made from July to October 1915) and lost for a long time.

An inspiration to create the suite "In white and black" was stipulated by the events in the country at war, however, there was felt a sound image method of thinking of the mature C. Debussy, who mirrored the takeaway from summer trip on the sea beach and his recollections about his last visit to Russia at the invitation of Serge Koussevitzky and Alexander Siloti.

The first part of Avec emportement (Fervently), dedicated to Serge Koussevitzky opens an epigraph from libretto by George Barbier and Michel Carré to Romeo and Juliet, an opera by Charles Gounod. It was created in Sonata rondo form: A B C $\mathrm{A}^{1}-\mathrm{C}-\mathrm{A}^{2} \mathrm{~B}^{1} \mathrm{C}^{1} \mathrm{~A}^{3}$ - coda. The variation changes taking place within the limits of rondo form accumulate the semantic load of romantic-connotative genre types (scherzo, waltz, march) and principles of form-making (the mix of features of rondo, sonata and variation form, through the development of the form of the unified type period). Genre and style "grounding" of the main sound images-themes - playful, ringing, fanfare, scherzo, melancholic, is based not on their kaleidoscopic but on the adjusting combination according to the principle of mutual transition-transformation.

The role of refrain plays the primary aria, built on Baroque principles of the unfolding of rhythm and texture formula, which expresses the symbol of perpetual motion. The general forms of motion (figurative thematic material)

${ }^{30}$ Kremliev, Yu. (1965). Clod Debussy. Moscow: Music. P. 684. 
personify through the genre-dancing archetype of the waltz. The symbol of perpetual motion, an aspiration for romanticized expression of sound sensation are associated with following words of the epigraph: "He who stays in his place and does not dance quietly admits to a disgrace" (translated by Oleksii Mashystov). Colouring-figurative background of the playful themeimage sets an impulse to a non-stop movement, and quasi-improvisation, prelusion - spontaneous and undetermined. Rhythm-texture complex of waltz brings closer to pictorial impressionism - gravitation towards depicting of the world in ever- changing takeaway from the objective world. Colouration is the main function of the figurative thematism.

On the other hand, in the first part, there were mentioned "dancing", "scherzo" and "march" imaging and their transformations. The use of genre at the bottom of dramaturgy of the instrumental forms, formed in the late creative works as "fixed genre-image zones" (the term of I. Umnova), are connected with the transformation of the theatrical principles of thinking into the pianoforte music. Besides, the composer used the principle of polygenre dramaturgy. The expositional section is constructed from plot-developed blocks, poly-thematic comparison of contrast episodes. Dramaturgy is traditional, with a culminating point in the episode before the coda, however, on the other hand, multicomponent symphonic. The example of the immensity and laconism of writing, long-form thinking, through unfolding principle. The primary existence of a conflict of two spheres is substituted for the unity of contrasts. The acceptance of coupling of actions different in time based on the combination of rhythmic, timbre, genre and genre and texture layers.

The second part - Lent. Sombre (Slowly. Sullenly), dedicated to the lieutenant Jacques Charlot, who died in 1915. The epigraph "Ballad against the enemies of France" by François Villon opens it:

Prince, may the bright-winged brood of Æolus

To sea-king Glaucus' wild wood cavernous

Bear him bereft of peace and hope's least glance,

For worthless is he to get good of us,

Who could wish evil to the state of France!

The theme of Luther's chant, which lies at the roots of the section, contradicts the sound play of the previous part. If the first part is associated with white, then the second one - with black, its tragic antipode. In the first measures, the tragic emotions amplify with the drop of the parallel third, which culminate with organ point. The tragic atmosphere is interrupted by the chord complex with sharp sff that sounds like a burst or despair. The phonic complex is made with two sound archetype - low, distant ringing sound, which develops in the culmination points into alarm bell and sounds of the last trump, fanfare. In the second section, there is reproduced the noise of 
approaching military march. The theme of the march is based on the chord complex in combination with fanfare and alarm bell in the culmination. In the coda the semantics of tonality $-C$-dur, dynamics $-f f$, motive complex, as a hint at the intonation of Marseillaise, graphically reproducing the victory over evil.

The third part (Scherzando) is dedicated to "My Dear Friend - Igor Stravinsky" and has an epigraph from the poetry of Charles of Orléans: "Winter's harsh cold...". Motive work with folk tunes - ascending thematic sound-timbre complex - the basis of the compositional technique of C. Debussy. The motive becomes the main structural element of the development, as long as it accumulates the energetic impulse, structurally and by means of timbre arranges the varying transformations of all the elements that interact both vertically and horizontally, avoiding traditional participation in the development of phrases, sentences and periods. Herewith the thematic function belongs not only to the melody but also to the harmony, rhythm, mode, and timbre. The form consists of laconic themes-motives, the smallest melodic meshes, from which "grow through" in the counterpoint combination their invariants and the whole form in general. The composer handles microstructures, filigree elements, laconic strokes-touches.

In such a way, noticeable for the sound symbolism of the late creative works of C. Debussy is the saturation of the postromantic view of life with kaleidoscopic play of sounds-impulses, images-concepts. It predetermines the type of the suite organization - macro-cycle, in which the independent microcycles (sections of the forms) are arranged. Such distribution reflects the logics of the dramaturgical development, established in the process of the individual-author's semantization of the verbal, genre, thematic and sound images-symbols:

1) verbal symbols - title, epigraph, subtitles, stage directions as character elements which perform the function of a metaphor;

2) genre-image symbols - typify through genre and form-making models, fixed in classical-romantic age (scherzo, waltz, march, "the mix" of features of rondo, sonata and variation forms and peculiarities of the construction of the instrumental miniatures - throughout development of the form of the single type period);

3) sound images-symbols - sound archetypes (ringing, a chime of bells, fanfare), sound complexes (micro-themes, motives) ascending whole tone tetrachord (a symbol of tragic ending, a harbinger of death);

4) sound-symbols - reference tone B (the Dorian mode) as a symbol of trouble, worry, fear.

The enrichment of classical models of the form with the innovative ideas (texture solutions, which uncovered timbre colouring of the pianoforte sound 
image, expanded the spatial properties of the musical sound), favours the renewal of the sound form, the increase of the role of the performer's thinking in the reproduction of the sound plasticity (articulation, dynamics, agogics, pedalization) and perception/seeing of the multidimensional conceptual space by the audience.

The sound poetics of C. Debussy's pianoforte is distinguished by lyric fineness, refinement, attention to every detail (harmonic idiom, texture formula, rhythm and intonation), multidimensional gradation of the sound colours within the limits of $p-p p p$, the diversity of timbre-dynamic, agogical nuancing. At the same time the dramatic collisions at the beginning of the $\mathrm{XX}^{\text {th }}$ century further significantly extended the limits of image-conceptual and timbre-dynamic means of artistic expressiveness, which leads to transformation of the sound image of the pianoforte pieces of music in the creative works of the $\mathrm{XX}^{\text {th }}$ century, which predetermines the end of modern European world picture (in the culture of the XVII-XIX ${ }^{\text {th }}$ centuries) and the beginning of the Contemporary history.

The new perception of the living reality (contemplation of the world, split personality and the world, dissociation from sociocultural context) was implicated by the composer with the symbolical images and senses. An important role in the interpretation of the sound image of the world played such properties of creative thinking of the composer as the intuition, imagination, fantasy.

The basis for the dramaturgical plan of his creative works became the adjusting method of the companying the musical-sound texture blocks, where the sound becomes the central element. The unfolding of the timbre-sounding field is considered by C. Debussy as the "sound magic", a secret transformation of the anthropomorphic world picture into the illusory, the world contemplative "poetry of sound".

Notwithstanding the traditional expectations of the audience, the sound world of C. Debussy's music is not genre or style criteria for the language creation. The expressiveness of the formed thematic nucleus, based on the connection of texture chord complexes, distances, motives in combination with wide melodic motions, stipulated by general "breathing" timbrecolouring background of the sound material. As a result, there is heard the overtone layer of pianoforte sounding, there is revealed "the soul" of the instrument, its inner voice. The performer shall reproduce these peculiarities of the post-romantic sensibility of the sound image of the world as a big creative-sound assignment, which reveals the symbolical program content of opus.

Sound dramaturgy of the pieces of music, which is created by means of "stringing", "escalating" of the sound weight, is treated as an organized 
creative-acoustic unity, unfolding in "luxury" of gradations of the timbre soundings. In the mind of the audience arises almost visible world, takeaway from the lyrical confession of the author, which corresponds to the formation of the symbolic type of musical imagery.

\section{CONCLUSIONS}

Sound is an important conceptual element, which integrates the entirety of the sound construction of the piece of music. The novelty of the sound-image thinking of C. Debussy, which is related to general processes, taking place in the musical creative life at the beginning of the XXth century, is expressed in the following points:

- the transformation of the semantic model of the world within the context of historical, conceptual and psychological preconditions of the evolution of the sound-image ideas about space, time, and movement;

- the formation of the concept of sound symbolization of the musical language-speech;

- metaphoricity of artistic thinking, which leads to laconism and aphoristic nature of musical expression;

- consolidation of the role of programming at the expense of extension of the methods and principles of the musical sound representation as a stylemaking factor;

- phychologization and symbolization of the sound image, which foresees the semantic load on each element of the musical space as a "time moment" in the chamber time and space of the pianoforte miniature;

- enrichment of the expressive means of the musical language (timbre, harmony, texture) with artistic methods and elements of pictorial writing techniques (plein air, water-colour drawing, stroke painting technique, a play of light and shadow);

- the novelty of sound thinking, which is characterized by independence and weakening of functional relationships of the tone, chord, harmony, prevailing of phonism, colouring, "colourful spots", "stiff" chords, modality, whole-tone, parallelisms by freedom of by-tonal superposition and modeharmony contrast;

- the spatial sense of the musical tone, which organizes the form and intonation -dramaturgical development - the sound as the process;

- expansion of the timbre-semantic position of the pianoforte as a universal poly-timbre instrument, which causes the search of new approaches to the problem of the performance interpretation, enrichment of the range of performance techniques and means. 
Image-semantic, structural characteristics and expressive potential of the musical sound at the same time become the field for the artistic innovation and experimentation in the sphere of individual and author's solutions, theme, dramaturgy and form-making, uncovering of timbrechord capabilities of the musical instruments. Due to these, there is achieved the potential for the pianoforte playing as the chamber and concert instrument, which has unlimited expressive possibilities. All these become the prevalent features of not only pianoforte creative works of C. Debussy as a representative of the musical impressionism but also of the sound image of the world at a tipping point of the end of the $\mathrm{XIX}^{\text {th }}$ the beginning of the $\mathrm{XX}^{\text {th }}$ centuries.

\section{SUMMARY}

The aim of the paperis to develop the sound poetics of C. Debussy, which reflect the sound image of the world. It is revealed that the specificity of sound-thinking C. Debussy discovers the world-modeling, semantic, timbre-coloristical and time-spatial parameters of musical sound, which broadened the boundaries of the sound-symbolic worldview. It is proved that in the work of C. Debussy, the concept of the sound is based on a spatially contemplative, introvert type of sound-musical expression. Sound dramaturgy of the pieces of music, which is created by means of "stringing", "escalating" of the sound weight, is treated as an organized creative-acoustic unity, unfolding in "luxury" of gradations of the timbre soundings.

The sound poetics of C. Debussy is determined by the holistic and diverse perception of sound, which is correlated to thinking with sound-images and is implicated in the semiotic structure of a piece of music in signs and symbols related to timbre and instruments. It has allowed us to reveal the nature of the transformation of the sound-image of the world, which consists in widening the sound-musical consciousness of artists and conceptualization of soundimage modelling of reality. Reproducing the world of post-romanticism images, genres, C. Debussy suggested own vision of the sounding space in a new focus of the sound-musical conscious. The composer uncovered the through (deep-volume, timbre-sounding, colour-phonic) perspective of the sound interior of the piece of music.

The article is based on the integrative approach, proceeding from a combination of general scientific (system, phenomenological) and special onto-sonological method, developed by the author of the article in his doctoral dissertation. 


\section{REFERENCES}

1. Kokoreva, L. (2010). Klod Debjussy: yssledovanye [Claude Debussy: the study]. Moscow: Music. (in Russian)

2. Klimova, N. (2011). "Pelleas y Melyzanda" K. Debjussy. K voprosu o suščnosty francuzskoho muzykal'noho symvolyzma ["Pelléas et Mélisande" C.Debussy To the question of the essence of French musical symbolism]. Kyiv Musicology. Kyiv. (in Russian)

3. Yarotsinsky, S. (1978). Debjussy, ympressyonyzm y symvolyzm [Debussy, Impressionism and Symbolism]. Moscow: Music. (in Russian)

4. Debussy, C. (1964). Stat'y, recenzyy, besedy [Articles, reviews, discussions]. Moscow: Music. (in Russian)

5. Gakkel, L. (1976) Fortepyannaja muzyka XX veka: očerky [Piano music of the XX century: essays]. Moscow-Leningrad: Sovetskij kompozitor. (in Russian)

6. Chashchina, S. (2012). Ynstrumental'noe tvorčestvo Kloda Debjussy: ot zvuka-atoma k zvuku-processu [Instrumental creativity of Claude Debussy: from sound-as-an-atom to sound-as-a-process]. Muzykovedčeskyj forum-2012: Materyaly meždunarodnoj naučnoj konferencyy [Musicological forum-2012: Proceedings of the international scientific conference,19-22.11.2012]. Moscow: Russian Academy of Music named after Gnesins. P. 12. Retrieved from: http://test.gnesin-academy.ru/sites/default/files/docs/Chashchina2Mb.pdf (accessed 10 January 2020). (in Russian)

7. Long, M. (1985). Za rojalem s Debjussy [At the piano with Debussy]. Moscow: Soviet composer. (in Russian)

8. Alschwang, A. (1963). Proyzvedenyy K. Debjussy y M. Ravelja [The piece of C. Debussy and M. Ravel]. M.: State Music Publishing House. (in Russian)

9. Denysov, E. (1986). Sovremennaja muzyka y problemy evoljucyy kompozytorskoj texnyky [Contemporary music and problems of the evolution of composer technique]. Moscow: Soviet composer. (in Russian)

10. Asafiev, B. (1975). Francuzskaja muzyka y eë sovremennye predstavytely [French music and its modern representatives]. Zarubežnaja muzyka XX veka [Foreign music of the twentieth century]. Moscow: Music. (in Russian)

11. Kunitskaya, I. (1978). Muzykal'nyj pejzazh Debyussy' [Musical landscape of Debussy]. Problemy pejzazha v evropejskom y'skusstvev XIX v.: matery'aly nauchnoj konferency'y' [Problems of landscape in European art of the 19th century: materials of the scientific conference]. M.: Soviet the artist. (in Russian)

12. Shvidka, N. (2015). Arxety'pny'j sy'mvol vody' yak marker ochy'shhennya, vidnovlennya ta vidrodzhennya $\mathrm{v}$ biblijnomu dy'skursi 
[The archetypal symbol water as a marker of purification, renewal and renewal in a biblical discourse]. Teorety'chni ta pry'kladni problemy' suchasnoyi filologiyi [Theoretical and applied problems of current philology]. Vol. 1. P. 160-164. Retrieved from: http://nbuv.gov.ua/UJRN/tppsf_ 2015_1_24. (accessed 10 January 2020). (in Ukrainian)

13. Kudriashov, Yu. (1985). Vly'yany'e Debyussy' na tembrovoe myshleny'e XX veka [The influence of Debussy on the timbre thinking of the twentieth century]. Problemy muzykal'noj nauky [Problems of musical science: Collection of scientific works], vol. 6. Moscow: Soviet composer. (in Russian)

14. Dovzhinets, I. (2006). Vidtvorennya plenerny'x efektiv u fortepiannij $m u z y$ 'ci [Plenary effects reproduction in piano music]. The thesis of Candidate of Art Criticism). Odessa National Musical Academy named after. A. V. Nezhdanova. Odessa. (in Ukrainian)

15. Izmailova, L. (1971). Chy'stye garmony'chesky'e tembry v muzyke K. Debyussy' [Pure harmonic tones in the music of K. Debussy]. Muzykoznany'e [Musicology]. Art. Vol. 5. (in Russian).

16. Izmailova, L. (1973). O tematy'cheskom sklade verty'kaly' v pozdny'x sochy'neny'yax [On the thematic vertical stock in the later works of Debussy]. Muzykoznany'e [Musicology]. Vol. 6. (in Russian).

17. Kremliev, Yu. (1965). Klod Debyussy' [Clod Debussy[. Moscow: Music. (in Russian).

\section{Information about the author:} Natalia Riabukha, Doctor of Art Criticism, Docent, Associate Professor at the Department of Piano Kharkiv State Academy of Culture, Kharkiv 4, Bursatski Uzviz, Kharkiv, 61057, Ukraine orcid.org/0000-0002-4182-0289 